\title{
Prohibition no, abolition yes! Rethinking how we talk about ending the cigarette epidemic
}

\author{
Ruth E Malone (10), ${ }^{1}$ Robert N Proctor (1) ${ }^{2}$
}

${ }^{1}$ Social and Behavioral Sciences, University of California, San Francisco, San Francisco, California, USA

${ }^{2}$ History, Stanford University, Stanford, California, USA

\section{Correspondence to} Professor Ruth E Malone, Social and Behavioral Sciences, University of California, San Francisco, San Francisco, CA 94118, USA;

ruth.malone@ucsf.edu

Received 27 October 2021 Accepted 28 December 2021

\section{Check for updates}

(c) Author(s) (or their employer(s)) 2022. No commercial re-use. See rights and permissions. Published by BMJ.

To cite: Malone RE, Proctor RN. Tob Control 2022:31:376-381

\section{ABSTRACT}

As public health advocates struggle over how best to end the cigarette epidemic, one persistent obstacle to developing appropriate policies has been the lingering spectre of 'prohibition'. A misunderstanding of the USA's experience with the national ban on sales of alcohol more than a century ago has led even public health advocates to claim that we cannot end the sale of cigarettes because 'prohibition does not work': a ban on sales, we hear, would lead to crime and to black markets, among many other negatives. In this Special Communication, we show how the tobacco industry has carefully constructed and reinforced this imagined impossibility, creating a false analogy between cigarettes and alcohol. This improper analogy, with its multiple negative associations, continues to block intelligent thinking about how to end cigarette sales. Instead of prohibition, we propose abolition as a term that better captures what ending sales of the single most deadly consumer product in history will actually do: enhance human health and freedom.

For decades, cigarette makers have equated smoking with liberty, proclaiming a 'right to smoke' while hinting that any restriction on the sale of cigarettes-indeed, any effective tobacco control at all-would be an infringement of fundamental freedoms. This has been particularly true in the USA, where, for example, Philip Morris sponsored a travelling exhibit of the original Bill of Rights in the 1980s. ${ }^{1}$ In opposing effective tobacco control, the tobacco industry often deploys the example of the USA's 1919 prohibition of alcohol sales, claiming that any effort to rein in such a fundamental liberty would result in chaos, crime or popular revolt: 'Prohibition failed the first time around, it won't work now'. ${ }^{2}$

This paper has two purposes. One is to deconstruct the tobacco industry's use and misuse of the prohibition analogy, by showing how the analogy is used to oppose a wide range of tobacco control policies, attack tobacco control practitioners and divide the tobacco control movement. A second purpose is to encourage using the more appropriate analogy of abolition for the proposal to end the sale of cigarettes. We suggest this reframing because we recognise that language is 'a loaded weapon'3 and because ending the sale of cigarettes is more accurately characterised as an enlargement of liberty, rather than its restriction. Cigarette makers have been masterful at confusing this issue, turning one of the world's most powerful addictions into an expression of freedom. A reorientation to the language of abolition is needed, because while prohibition implies a curtailing of freedom, abolition implies liberation from a malignant practice or institution.

\section{THE PROHIBITION ANALOGY}

Governments routinely ban or limit various types of activities deemed unsafe or harmful. Such laws may involve restrictions on personal behaviours that affect others, prohibitions on purchase of dangerous products or bans on the sale of such products. In the case of cigarettes, Big Tobacco has worked to create and perpetuate a false comparison to the USA's experience with alcohol prohibition more than a century ago, shaping notions about consumer product safety that have become a roadblock to responsible government action.

How has the moth-eaten spectre of prohibition become such an effective way to shut down any talk of stopping cigarette sales? Why does this analogy retain such power? What do people fear when they think we cannot ban the sale of cigarettes? The prohibition analogy draws its power from several imagined negatives, including crime, crusading moralism and a deprivation of personal choice.

\section{THE SPECTRE OF A BLACK MARKET AND ORGANISED CRIME}

For decades, cigarette makers have warned that a ban on cigarette sales-or even on a particular additive like menthol-would lead to a black market or worse. Many of the 10651 documents in the Truth Tobacco Industry Documents library ${ }^{4}$ on 'organised crime', the 17242 documents on 'bootlegging' and the 588 documents on 'criminal gangs' in the industry's files sound this alarm. Philip Morris in 1996, for example, while pondering the acquisition of News Corporation (owner of Fox) from Rupert Murdoch, was also contemplating engaging 'a noted historian to prepare a series of weekly columns about prohibition and its negative implications', with a focus on 'organised crime'.

\section{THE SPECTRE OF A MORAL CRUSADE}

For decades, cigarette makers have argued that any effort to limit the sale or use of cigarettes constitutes an unjustified interference in people's lives by 'the nanny state', another aspect of the prohibition trope. Public health advocates by this reckoning are just busybodies trying to tell us all how to live our lives; we are 'shower-adjusters' (334 documents) and zealots (13781 documents), arch-enemies of fun and freedom. ${ }^{4}$ 
Box 1 What was prohibition?

After a vigorous campaign centred around protection of families from the deleterious effects of drink, the US Congress prohibited the manufacture and sale of alcohol in 1919, taking effect in $1920 .^{59}$ The policy was initially popular with many people and alcohol consumption and its adverse effects were reduced. Although consumption was never banned, and those with a stock of alcohol could drink it legally, as stocks ran low the policy became increasingly unpopular and black market sales proliferated through underground 'speakeasies', with protection from organised crime figures like Al Capone. ${ }^{60}$ Prohibition was abandoned federally in 1933, though some state and local jurisdictions continued their bans, as do some even to the present day ('dry counties'). ${ }^{61}$

\section{THE SPECTRE OF LOSS OF PERSONAL CHOICE}

Talk of prohibition also dovetails with the idea that anything that interferes with personal choice is bad. Public health scholars have long recognised the poverty of this approach when applied to cigarettes. The 1989 US Surgeon General's report identified two principal flaws in this 'personal choice' argument: (1) the young age at which people start smoking and (2) the power of addiction (pp. v-vi). ${ }^{6}$ Years before, even cigarette makers had acknowledged privately that 'the argument revolving around "free choice"' was being 'negated on the grounds of addiction'? Public health advocates have often called attention to how 'freedom' and 'choice' are constrained by social circumstances, including marketing to disadvantaged groups and the deliberate engineering of cigarettes to be maximally addictive. ${ }^{89}$

\section{CRAFTING THE 'PROHIBITION' BOGEYMAN}

The tobacco industry has created a bogeyman by routinely characterising any rigorous tobacco control measure as 'de facto' or 'the road to' prohibition. A scarecrow image of the actual history of alcohol prohibition is created by such comparisons, which tend to be naïve and simplistic, ignoring the historical complexities surrounding such policies (including certain health benefits) ${ }^{10}$ (box 1). Cigarette makers also tend to conflate banning sales with restricting or punishing personal use, which allows them to paint advocates for banning sales as restricting personal liberties. Cigarette makers weaponize such confusions to divide the tobacco control community and to render 'impossible' any path leading to effective abolition.

For decades, cigarette makers have used the term prohibition as a derogatory label for any kind of effective tobacco control. The Tobacco Institute's Ann Browder in 1979, for example, claimed that smoking bans in restaurants constituted 'piecemeal prohibition', ${ }^{11}$ and 30 years later industry allies cited the danger of a black market to oppose the Food and Drug Administration's efforts to remove menthol from cigarettes. ${ }^{12} 13$ Cigarette makers have raised the spectre of prohibition to defeat efforts to ban sales to minors, and to delay restrictions on smoking in airplanes and in restaurants (p. 12). ${ }^{14}$ The word 'prohibition' appears in $>156000$ documents in the Truth repository, with many of these stressing the impossibility of limiting the sale or use of cigarettes. The dangers of 'prohibition' were always part of the talking points of the Tobacco Institute, which repeatedly warned of 'creeping prohibition' (299 documents), 'backdoor prohibition' (1105 documents) and 'prohibition through taxation' (110 documents). ${ }^{4}$ This strategy dates from the earliest phases of the industry's denial campaign: Hill and Knowlton when crafting the industry's public relations strategy stressed the value of drawing attention to the 'dangers of prohibition' along with the 'social benefits of smoking'. 15

Raising the spectre of prohibition was also part of the industry's litigation strategy. Law firm Shook Hardy and Bacon, in a training manual for trial counsel, stressed that any effort to rein in tobacco should be labelled 'De Facto prohibition (p. 10)'. ${ }^{16}$ Cigarette makers paid popular magazines to denounce prohibition: Barron's Weekly in 1967, for example, published an attack on 'The Federal Crusade Against Smoking', where warnings of a cigarette-cancer link were said to be part of an elaborate effort by bureaucrats 'to brainwash the citizenry into kicking the habit... a crusade as menacing and ugly as prohibition'. ${ }^{17}$ Barron's never revealed that its pro-cigarette articles were written with the aid of the Tobacco Institute, which privately bragged about its role in financing and planting those articles. ${ }^{18}$

Cigarette makers have also hired historians to help craft the narrative of impossibility, equating prohibition with the 'failed' experience of alcohol in the USA. John Burnham at Ohio State, for example, was hired to testify for the industry in court, after demonstrating his willingness to write cigarette-friendly histories of (alcohol) prohibition. ${ }^{19}$ Burnham directed Philip Morris' ambitious Project Cosmic, the goal of which was to assemble a global team to denounce efforts to limit smoking. ${ }^{20}$ Burnham later bragged about being the industry's 'mole' in academia, ${ }^{21}$ recruiting scholars like James Kirby Martin and Mark Lender, who had co-authored Drinking in America, published by the Free Press in 1987. Martin later testified for the industry: "We had talked about doing... a companion volume which would continue an investigation of questions of prohibition". Martin and Lender's project, which had the working title 'Banned in the USA', was abandoned when Lender developed a mouth tumour (pp. 185-6). ${ }^{22}$

The prohibition trope has also been deployed outside the USA. In Australia, for example, the Australian Tobacco Manufacturing Industry prepared a document in 1969 echoing the Barron's Weekly article, arguing against cigarette health warning labels and advertising bans by referencing 'a crusade as menacingly ugly as prohibition was in the years following the first World War'. ${ }^{23}$ The chief executive of Australian tobacco group W.D. and H.O. Wills was quoted in a 1995 media release as saying that increasing tobacco taxes 'amounts to backdoor prohibition'. ${ }^{2425}$ In London, the Freedom Organisation for the Right to Enjoy Smoking Tobacco, a 'smokers' rights' group supported by tobacco companies, in 1990 published a treatise entitled 'A short history of 500 years of the use and prohibition of tobacco'. ${ }^{26}$

For the industry, the USA's experience of alcohol prohibition is always wholly negative, despite accounts suggesting thatas a measure to reduce the adverse health and social effects of alcohol consumption-it was actually effective and, at least initially, quite popular with the public. ${ }^{1027}$ The prohibition trope is thus based on a misreading of history and a faulty equivalence of alcohol and tobacco. ${ }^{102728}$ But it has also become a shorthand for something more sinister: the idea that governments cannot be trusted to act in the interests of the people. Simon Chapman and others have pointed out that 'nanny state' has saved innumerable lives through policies now mostly taken for granted. ${ }^{28} 29$ In richer parts of the world, we assume that our water will be clean and sewage properly disposed; we live with emissions controls on factory stacks and building codes that are essentially 'prohibitions'. ${ }^{29}$ Powerful corporations often resist efforts to mandate such protections - think of how long it took to ban lead from the paint on children's toys, ${ }^{30}$ and how hard it has proved 
to limit greenhouse gas emissions. ${ }^{31}$ Denouncing 'prohibition' in the abstract effectively serves the interests of polluting industries, by weakening trust in public health governance. Cigarette makers in the 1980s and 1990s joined with Big Oil to help create political movements like the Tea Party, figuring that if they could taint the whole idea of taxation and regulation, then sellers of gasoline and cigarettes could continue doing business as usual. ${ }^{32}$

Big Tobacco has also worked to promote an understanding of prohibition as making criminals of people who grow or smoke tobacco. In 1984, for example, Tobacco Institute President Horace Kornegay, in a speech to Burley warehousers, castigated US Surgeon General C. Everett Koop as the 'executioner' of tobacco farmers. After further comparing the Surgeon General and his advisors to Hitler Youth and China's Red Guards, Kornegay wondered what Koop's 'final solution' would be for those 'recalcitrant' smokers who did not obey his order to quit: 'Exile? Deportation? Concentration Camps? Death squads?' The former North Carolina congressman labelled Koop 'a grave threat to millions of Americans', given his plot to bring us a world of 'prohibition, segregation, discrimination' and 'antismoking apartheid'. 33

\section{ADOPTION OF THE PROHIBITION TROPE BY PUBLIC HEALTH ADVOCATES}

Unfortunately, public health authorities have long accepted the cigarette industry's framing of what is or is not possible, conjuring this same prohibition bogeyman. President Kennedy's Health Education and Welfare Secretary Anthony J. Celebrezze, for example, in 1962 rejected calls for federal action against cigarettes, claiming it was 'not the proper role of the federal government to tell citizens to stop smoking'. Celebrezze's explanation: 'prohibition did not work'. The Secretary's position was perhaps influenced by the fact that he himself smoked a pack a day. $^{34}$

Even those we associate with courageous tobacco control have feared the prohibition trope. In 1969 Congressional testimony, Action on Smoking and Health founder John Banzhaf argued that cigarette sales should not be banned, because this would lead to a black market and therefore 'will not work' (p. 289)..$^{35}$ Several past US Surgeon General reports have similarly disclaimed the possibility of prohibiting sales of cigarettes (or smoking), usually without citing any evidence. The 1984 report on chronic obstructive lung disease asserted that 'outright prohibition' was 'not feasible... not an acceptable alternative' (pp. 520, 527). ${ }^{36}$ The editors of the Journal of the American Medical Association, in a 1986 editorial, claimed that a ban on the sale of cigarettes, however 'tempting' to contemplate, would 'inevitably fail': "We would be faced with a second Prohibition, everywhere undermining respect for law and encouraging the growth of organized crime to new and more massive proportions". ${ }^{37}$

Cigarette makers have been pleased-and often surprised-by how reluctant public health authorities have been to embrace the idea of a ban on sales. Some in the industry actually anticipated such a ban after the 1964 Surgeon General's report, and Philip Morris was privately relieved that the report had left smoking on 'an individual basis'. ${ }^{38}$ The Tobacco Institute also appreciated the 'moderate' approach of the American Cancer Society, which had positioned itself intermediate between 'prohibitionists' and 'accommodationists'. 39

More recently, cigarette makers have raised the spectre of prohibition to divide the tobacco control movement, specifically by contrasting the industry-preferred version of 'harm reduction' with 'prohibitionists'. A 2014 Philip Morris International (PMI) strategy document ${ }^{40}$ calls for amplifying 'voices of "harm reduction"' versus 'prohibitionists', stressing the need to 'marginalise the policies and advocates of extreme measures as prohibitionists'. 'Extreme measures' for PMI included bans on menthol and other additives, policies to mandate nicotine reductions, point of sale display bans and policies to require larger graphic warnings on packaging.

\section{ARE CIGARETTES LIKE BEER?}

A misunderstanding of alcohol prohibition from over a century ago has thus been twisted by the industry into a shorthand for conveying several ideas about tobacco products that ill-serve health and human liberty, making it hard to imagine that sales of cigarettes could ever be ended. ${ }^{4142}$ Part of the prohibition myth is the public health community's ongoing, often uncritical adoption of cigarette industry framings. A great deal of public health rhetoric is unwittingly tainted: talk about 'smoking' (rather than cigarettes) causing cancer, for example (which blames the victim), or referring to 'smoking and health' rather than 'cigarettes and death'. And why is the burden of 'cessation' always on the consumer and never the producer? Public health advocates use the term prohibition when talking about ending cigarette sales, because we have uncritically adopted the industry's equation of cigarettes with beer or wine. Here is where the work of analogies is key, because if cigarettes really were like beer, then a ban on sales might well be undesirable or unworkable.

But cigarettes are not like beer. They are not like beer, because (a) cigarettes are far more deadly, and (b) most people who drink do not become addicted. For most people alcohol is a recreational drug, which is very different from the nicotine delivered in cigarette form. Only about $5 \%-10 \%$ of people who drink are addicted, versus $>80 \%$ of people who smoke cigarettes (p. 493). ${ }^{43}$ The fundamental argument for ending sales of cigarettes (vs prohibition of alcohol) is really twofold: cigarettes are powerfully addictive and far more injurious, and most people who smoke wish they did not. The oddity of cigarettes is that most of the demand stems from addiction, which is why medical professionals often prescribe alternative means of delivering nicotine, on a therapeutic (rather than recreational) basis. And the contrast with heroin is instructive: we do not allow retail sales of heroin and other highly addictive drugs, even in countries where their use is decriminalised. For addicted smokers, the ubiquitous retail availability of cigarettes makes quitting even more difficult. ${ }^{445}$ Cigarettes are unlike beer and more like heroin, because almost everyone who smokes eventually regrets having started. ${ }^{46}$

\section{THE ABOLITION ALTERNATIVE}

How can we reframe our discourse to deflate the prohibition bogeyman and make planning for the end of cigarette sales seem less onerous and more achievable? Understanding the ways in which the tobacco industry has deployed the prohibition bogeyman is a first step. But a second step is to recall that responsible governments often ban the sale of products that harm people, including many that are much less injurious than cigarettes.

In 1988, for example, the US Consumer Product Safety Commission banned the sale of lawn darts, an outdoor game involving throwing sharp metal-tipped objects, after three deaths and several hundred injuries caused by the products. ${ }^{47}$ Many national governments have banned the sale of lead-containing paint, dangerous pharmaceuticals and pesticides of various sorts, including some formerly in widespread use. Few would now 
Box 2 What is abolition?

After centuries of transatlantic slave trade, President Abraham Lincoln announced the liberation of American slaves through the Emancipation Proclamation of 22 September 1862. For decades, abolitionists had struggled to end the practice of slavery, with some favouring only the abolition of the slave trade, while others called for the abolition of the entire institution. Britain had abolished its trade in slaves in 1807, for example, while still allowing possession of enslaved humans in British colonies. Abolition has also been applied to the ending of child labour or unfair taxes: the word implies the ending of an onerous institution. Key to understanding this terminologic distinction is that while 'prohibition' implies a loss of freedom, 'abolition' invokes its enlargement, as in freedom from slavery. Prohibition is more about building walls: abolition is about tearing them down.

assert that heroin, once seen as a useful therapeutic drug, should be widely available for sale in gas stations or grocery stores. ${ }^{48}$ These are all instances in which long-accepted products and practices have been abolished.

Why is abolition a better way to think about ending the cigarette epidemic? ${ }^{49}$ First and foremost is the fact that smoking is less an expression of liberty than its deadly robbery. Most (cigarette) smokers wish they did not smoke, ${ }^{46}$ which means that human liberties will actually be enlarged by eliminating sales of cigarettes (box 2). The industry has worked very hard to trivialise our understanding of addiction: they want us to believe that addiction is essentially desire, when addiction is more like the frustration of desire. If most people who smoke wish they did not, then ending sales of cigarettes will make it easier for smokers to regain the freedom not to smoke. Achieving this freedom is not made easier by the fact that for every McDonalds in the USA, there are 27 retail outlets for cigarettes. Ease of access sustains the epidemic.

Abolition also recalls the end of slavery and other unjust institutions. Abolition means 'the complete ending' of a cruel or onerous custom, carrying the rhetorical gravitas of noble work to end slavery, child labour, torture and other inhumane (but once common) practices. The language of abolition also allows public health to challenge a fundamental (and outrageous) talking point of the industry: that smoking is 'natural' for humans and that nothing can really be done to stop it. Humans according to this view will always want to smoke, and efforts to end sales are doomed to fail. But this is untrue: the cigarette epidemic is itself a historical creation of Big Tobacco, built and sustained by human actors. It can be ended by human action.

More accurately than prohibition, abolition reflects what ending cigarette sales would actually do: liberate humanity from the world's most lethal consumer product, a product which has caused untold human suffering and which most users would rather do without. The normalisation of cigarettes has led to the premature deaths of $>100$ million people in the last century, ${ }^{50}$ and even more in our present century. ${ }^{51}$ Humans will always suffer from microbial epidemics, but the cigarette variant differs in being caused by transnational corporate actors being permitted to prioritise profits over human lives.

Abolition refocuses attention from the individual consumer to the corporate producer and the means by which the epidemic is spread, wholesale and retail. In coming to grips with obesity, scholars have recognised that blame cannot be placed solely on personal sloth and gluttony: the epidemic has structural, political and social causes, having to do with sugar production and marketing, corporate power and the ubiquity of sugared drinks. ${ }^{52}$ With tobacco, too, we need to move beyond thinking of the cigarette catastrophe as the result of bad personal choices. The epidemic has corporate causes with retail and political accomplices.

In arguing for abolition, we do not envision an overnight ban on sales everywhere. We are calling for governments to develop concrete, phased plans for ending sales. Phasing out cigarette sales, challenging though it may be, is simpler and more effective than endlessly cajoling millions to eschew something sold in nearly every gas station and convenience store. Abolition is consistent with how we approach cholera or tainted meat: we go upstream, and look for points where we can stop the toxin at its source. Cigarettes are like cholera in this sense: we need to treat not just the disease but how it is caused and spread.

Abolishing the sale of cigarettes will not be easy. The tobacco industry and its allies remain powerful and there are structural, political and social barriers to be overcome. Despite these constraints, people and governments are not helpless to act.

\section{ENTIRELY WITHIN OUR POWER, ENTIRELY WITHIN OUR RIGHTS}

It is important for public health advocates to appreciate how cigarette makers have used the false analogy of 'prohibition' to block progress in tobacco control. This means calling out the industry and its allies when the term is used, but also rejecting the prohibition trope when invoked pejoratively by public health colleagues to marginalise advocates of policies they fear will be unworkable. The public health effort to end the cigarette epidemic will be more likely to succeed by casting off the industry's framings.

As wrong as it is to underestimate Big Tobacco's power, it is also wrong to exaggerate it. In 2021, 148 public health organisations from across the globe called on governments to develop plans to phase out cigarette sales, and others have set out plans to dramatically reduce retail availability. ${ }^{53}$ Even in the USA, where the industry remains influential at the national level, local communities and/or state governments have it entirely within their power-and legal right- to end the sale of cigarettes. There is solid legal precedent for such actions dating back over a 100 years, when the US Supreme Court in Austin vs Tennessee (1900) upheld the right of any state or local community to abolish the sale of cigarettes. From 1890 to 1927, 16 US states successfully banned the sale (and sometimes manufacture) of cigarettes, with no great outcry over deprivation of liberties-apart from protests from the usual suspects. ${ }^{55}$ In more recent times, there have been many local attempts to end the sale of cigarettes, some of which might have succeeded if public health organisations had been less spooked by the spectre of prohibition. ${ }^{56}$

Abolition is no longer a pipe dream. Two California cities have recently enacted ordinances ending the sale of most tobacco products, both of which went into effect in January 2021. So far no surge in black markets, no rise in criminal gangs, no reported suffering from deprivation of liberty. We can expect other cities to follow suit, forming an ever-expanding quilt of truly smokefree communities. ${ }^{57}$ Public health leaders need to recognise that the language of abolition could be useful in helping governments move past the prohibition trope to correct more than a century of industry-created public health injustice.

Tobacco control organisations must advocate for abolishing the sale of cigarettes, the only consumer product most users 
wish they did not use. We should not be comfortable in a world where the most vocal organisation calling for an end to smoking is a transnational tobacco giant engaged in yet another image makeover. ${ }^{58}$ To paraphrase Nelson Mandela: difficult tasks often seem impossible, until they are actually done. Like abolition of apartheid or slavery, abolishing the sale of cigarettes will signal the end of our passive-and pathological-acceptance of these lethally addictive contrivances and their constraints on human freedom.

\section{Twitter Ruth E Malone @MaloneRuth}

Acknowledgements The authors thank Elizabeth A. Smith and Patricia A. McDaniel for helpful comments on earlier versions of this paper and assistance with references and formatting, and Carol McGruder for fruitful discussions and talks linking the tobacco endgame with abolishing slavery and apartheid. The authors also acknowledge the helpful comments of three reviewers whose insights about successive versions of the paper were appreciated.

Contributors Both authors conceptualised the paper and wrote and edited all versions.

Funding The authors have not declared a specific grant for this research from any funding agency in the public, commercial or not-for-profit sectors.

Competing interests REM ORCID: https://orcid.org/0000-0002-3324-2183, Professor Emerita, University of California, San Francisco; editor-in-chief, Tobacco Control Date: 31 July 2021. I have read and understood BMJ's policy on declaration of interests and declare the following: personal financial interests: since 1997, I have been a faculty employee of the University of California, San Francisco. I am semi-retired and receive a pension from the University. My recall salary is provided by funds from the state of California and my research grant from the National Cancer Institute. I have received travel/accommodation expenses and consulting fees or honoraria from the US Department of Justice (for serving as a tobacco industry documents consultant for USA vs Philip Morris et al), WHO (for serving on the Expert Panel on Tobacco Industry Interference with Tobacco Control), American Legacy Foundation (for serving on an award selection panel), Clearway Minnesota (for serving as a grant proposal reviewer), US Centers for Disease Control (for consulting on a tobacco industry documents research project), NIH (for serving as a grant proposal reviewer) and Cancer Research UK (for preparing a report on views of the idea of a tobacco 'endgame'). I own one share each of Philip Morris International, Reynolds American and Altria stock for research and advocacy purposes and have participated in tobacco control advocacy. I receive an annua honorarium and reimbursement of travel/accommodation expenses from BMJ Publishing Group Ltd (for work as editor-in-chief of Tobacco Control). I have also received travel/accommodation expenses and honoraria for speaking to various public health groups. In addition, I have received funding for reviewing documents as a potential expert witness for plaintiffs' legal cases involving tobacco industry activities. Organisational financial interests: within the last 5 years, I have received grant funding from the National Cancer Institute, National Institutes of Health, the California Tobacco-Related Disease Research Program (research funds derived from the state tax on cigarettes) and the California Tobacco Control Program. RNP is a tenured faculty member at Stanford University and receives a salary. He also serves as an expert for plaintiffs in tobacco litigation, where the industry has been charged with fraud, conspiracy, negligence, racketeering and/or manufacture of a deadly product.

Patient consent for publication Not applicable.

Ethics approval This study does not involve human participants.

Provenance and peer review Commissioned; externally peer reviewed.

ORCID iDs

Ruth E Malone http://orcid.org/0000-0002-3324-2183

Robert N Proctor http://orcid.org/0000-0002-8910-5647

\section{REFERENCES}

1 Conroy SB. Fired up over Philip Morris. Available: https://www.washingtonpost.com/ archive/lifestyle/1989/11/10/fired-up-over-philip-morris/bc2a1531-9c32-47e5-abfdefe7bce3c829/ [Accessed 6 Dec 2021].

2 Mott G, Shanken MR. Cigar Aficionado. defend your rights. April 2000. Philip Morris records. Available: https://www.industrydocuments.ucsf.edu/docs/mhlw0080

3 Bolinger DLanguage, the loaded weapon: The use and abuse of language today. New York: Longman, 1980.

4 Truth tobacco industry documents. Available: https://www.industrydocuments.ucsf. edu/tobacco/ [Accessed 6 Dec 2021].
5 Smith GL. Smith Worldwide. "Alternative" Communications. September 101996. Philip Morris Records. Available: https://www.industrydocuments.ucsf.edu/docs/ sqfb0152

6 US Department of Health and Human Services. Reducing the health consequences of smoking: twenty-five years of progress, 1989.

7 Pepples E. Confidential Communication From B\&W in-House Counsel to B\&W Management Requesting Information Regarding Various Smoking and Health Issues to Facilitate the Rendition of Legal Advice in Anticipation of Litigation. February 14 1973. Brown \& Williamson Records. Available: https://www.industrydocuments.ucsf. edu/docs/qsml0041

8 Fox BJ. Framing tobacco control efforts within an ethical context. Tob Control 2005;14 Suppl 2:ii38-44.

9 Friedman LC. Tobacco industry use of corporate social responsibility tactics as a sword and a shield on secondhand smoke issues. J Law Med Ethics 2009;37:819-27.

10 Hall W. What are the policy lessons of national alcohol Prohibition in the United States, 1920-1933? Addiction 2010;105:1164-73.

11 Tobacco Institute Newsletter. October 30 1979. tobacco Institute records. Available: https://www.industrydocuments.ucsf.edu/docs/mzbv0048

12 Zid Abu-Shalback L. Menthol ban = black market. Lorillard, NACS, others speak out on potential ban's side effects. CSP Daily News, 2010. https://www.thecre.com/news/ 20101122_news.htm

13 Tozzi J. Remarks of Jim Tozzi of the center for regulatory effectiveness before the National Foundation of women legislators forum on illicit tobacco trade, 2014. Available: https://www.womenlegislators.org/wp-content/uploads/2016/02/centerfo rregulatoryeffectiveness-illicittobaccotrade.pdf [Accessed 26 Oct 2021].

14 Judge C. Comments to the tobacco growers association of North Carolina. November 17 1983. tobacco Institute records. Available: https://www.industrydocuments.ucsf. edu/docs/tlpm0051

15 Hill \& Knowlton. Some proposals for tobacco industry public relations. April 251967. tobacco Institute records. Available: https://www.industrydocuments.ucsf.edu/docs/ pmwy0059

16 Pepples E, Stevens A, G NJ. Training Materials for Counsel in Smoking \& Health Litigation. Volume III New Cases: 1982. Anti-Smoking and Plaintiff Organizations. Defense Organization. Plaintiff's Legal Theories, Factual Allegations, Strategy. August 1986. RJ Reynolds Records. Available: https://www.industrydocuments.ucsf.edu/docs/ kkgn0174

17 Barrons. Dangerous Lengths the Federal Crusade against Smoking Has Gone Too Far. October 02 1967. Brown \& Williamson Records. Available: https://www. industrydocuments.ucsf.edu/docs/jhhx0057

18 Clements EC. Remarks by Earle C Clements president annual meeting the tobacco Institute Inc Thursday January 26 1967. January 26 1967. tobacco Institute records. Available: https://www.industrydocuments.ucsf.edu/docs/fqkn0049

19 Burnham JC. Bad habits: drinking, smoking, taking drugs, gambling, sexual misbehavior and swearing in American history. New York: NYU Press, 1993.

20 Proctor RN. "Everyone knew but no one had proof": tobacco industry use of medical history expertise in US courts, 1990-2002. Tob Control 2006;15 Suppl 4:iv117-25.

21 Rasmussen N, Proctor RN. From maverick to mole: John C. Burnham, tobacco consultant. Isis 2019;110:779-83.

22 Martin JK. Iron workers local Union No. 17 insurance fund and its trustees, et al. vs. Philip Morris, Inc., et al. deposition of James Kirby Martin volume I. January 15 1999. RJ Reynolds records. Available: https://www.industrydocuments.ucsf.edu/docs/ hknc0093

23 Australian Tobacco Mfg Industry. Arguments in support of the tobacco industry case against health warning labels on cigarette packets and the banning of cigarette advertising. July 1969. Philip Morris records.. Available: https://www. industrydocuments.ucsf.edu/docs/xzyf0128

24 Riordan M. True Believers fund a new GST. May 09 1995. British American tobacco records. Available: https://www.industrydocuments.ucsf.edu/docs/knxg0202

25 RJ Reynolds International. RJRTI News Report. Australia. WD \& HO Wills Criticizes Tobacco Tax Rise. May 12 1995. RJ Reynolds Records; Master Settlement Agreement. Available: https://www.industrydocuments.ucsf.edu/docs/qzkn0013

26 Gabb S. Forest. smoking and its enemies: a short history of 500 years of the use and Prohibition of tobacco. 1990. Tobacco Institute records. Available: https://www. industrydocuments.ucsf.edu/docs/mrwn0039

27 McGirr L. The war on alcohol: Prohibition and the rise of the American state. New York: WW Norton and Co, 2016.

28 Proctor RN. Golden holocaust: Origins of the cigarette catastrophe and the case for abolition. Berkeley: University of California Press, 2011.

29 Chapman S. One hundred and fifty ways the nanny state is good for us, 2013. Available: https://theconversation.com/one-hundred-and-fifty-ways-the-nanny-stateis-good-for-us-15587 [Accessed 26 Oct 2021].

30 Markowitz G, Rosner D. Lead Wars: The Politics of Science and the Fate of America's Children. Oakland. University of California Press, 2013.

31 Wallace-Wells D. The Uninhabitable earth: Life after warming. New York: Tim Duggan Books, 2020

32 Nesbit J. Poison tea: How big oil and big tobacco invented the tea Party and captured the GOP. New York: St. Martin's Press, 2016. 
33 Kornegay H. Remarks of Horace R. Kornegay - Burley Auction Warehouse Association - Asheville, North Carolina - May 31, 1984. May 31 1984. Tobacco Institute Records. Available: https://www.industrydocuments.ucsf.edu/docs/rlgm0146

34 Tucson Star. Smoking left to public by health chief. December 03 1962. American Tobacco records. Available: https://www.industrydocuments.ucsf.edu/docs/fpdm0137

35 Part 1 Cigarette Labeling and Advertising - 1969. Hearings before the Committee on Interstate and Foreign Commerce House of Representatives. 1969. Philip Morris Records. Available: https://www.industrydocuments.ucsf.edu/docs/kpkw0189

36 US Department of Health and Human Services. The health consequences of smoking: Chronic obstructive pulmonary disease, 1984. Available: https://collections.nlm.nih. gov/ext/document/101584932X476/PDF/101584932X476.pdf [Accessed 26 Oct 2021].

37 Lundberg GD, Knoll E. Tobacco: For consenting adults in private only. JAMA 1986;255:1052.

38 Weissman G. Surgeon General's Report. January 29 1964. Philip Morris Records Available: https://www.industrydocuments.ucsf.edu/docs/ggnw0128

39 Tobacco Institute. Tobacco Institute Newsletter special report. October 071971. Council for Tobacco Research records. Available: https://www.industrydocuments.ucsf. edu/docs/fffb0215

40 Philip Morris International. 10 year corporate Affairs objectives and strategies, 2014. Available: https://s3.documentcloud.org/documents/4333395/10-Year-CorporateAffairs-Objectives-and.pdf

41 Malone RE. Imagining things otherwise: new endgame ideas for tobacco control. Tob Control 2010;19:349-50.

42 Malone RE. Tobacco endgames: what they are and are not, issues for tobacco contro strategic planning and a possible us scenario. Tob Control 2013;22 Suppl 1:i42-4.

43 American Psychiatric Association. Diagnostic and statistical manual of mental disorders. 5 edn. Arlington, VA: Author, 2013.

44 Wakefield M, Germain D, Henriksen L. The effect of retail cigarette pack displays on impulse purchase. Addiction 2008;103:322-8.

45 Burton S, Clark L, Jackson K. The association between seeing retail displays of tobacco and tobacco smoking and purchase: findings from a diary-style survey. Addiction 2012;107:169-75.

46 Fong GT, Hammond D, Laux FL, et al. The near-universal experience of regret among smokers in four countries: findings from the International tobacco control policy evaluation survey. Nicotine Tob Res 2004;6 Suppl 3:341-51.

47 United States Consumer Product Safety Commission. CPSC votes final ban on lawn darts, 1988. Available: https://www.cpsc.gov/Newsroom/News-Releases/1989/CPSCVotes-Final-Ban-On-Lawn-Darts [Accessed 26 Oct 2021].
48 United Nations Office on Drugs and Crime. History of heroin, 1953. Available: https:// www.unodc.org/unodc/en/data-and-analysis/bulletin/bulletin_1953-01-01_2_ page004.html [Accessed 6 Dec 2021].

49 Proctor RN. Why ban the sale of cigarettes? the case for abolition. Tob Control 2013;22 Suppl 1:i27-30.

50 Proctor RN. Tobacco and the global lung cancer epidemic. Nat Rev Cancer 2001;1:82-6.

51 World Health Organization. WHO report on the global tobacco epidemic, 2017: monitoring tobacco use and prevention policies, 2017. Available: https://apps.who.int/ iris/handle/10665/255874 [Accessed 6 Dec 2021].

52 Lustig R. Fat chance: beating the odds against sugar, processed food, obesity, and disease. New York: Plume, 2013.

53 Action on Smoking and Health. Letter: 148 organizations call for phasing out sales of combustible tobacco products, 2021. Available: https://ash.org/aftertobacco/ [Accessed 26 Oct 2021].

54 New Zealand Ministry of Health. Proposals for a smokefree Aotearoa action plan, 2021. Available: https://www.health.govt.nz/publication/proposals-smokefreeaotearoa-2025-action-plan [Accessed 26 Oct 2021].

55 Linder M. "Inherently Bad, and Bad Only": A History of State-Level Regulation of Cigarettes and Smoking in the United States since the 1880s. Iowa City, IA, 2012

56 McDaniel PA, Malone RE. Tobacco industry and public health responses to state and local efforts to end tobacco sales from 1969-2020. PLoS One 2020;15:e0233417.

57 Smith EA, Malone RE. An argument for phasing out sales of cigarettes. Tob Control 2020;29:703-8.

58 Wood Z. Tobacco firm Philip Morris calls for ban on cigarettes within decade. The guardian, 2021. Available: https://www.theguardian.com/business/2021/jul/25/ tobacco-firm-philip-morris-calls-for-ban-on-cigarettes-within-decade

59 Andrews E. 10 things you should know about Prohibition, 2019. Available: https:// www.history.com/news/10-things-you-should-know-about-prohibition [Accessed 26 Oct 2021].

60 Roos D. How Prohibition put the 'organized' in organized crime, 2021. Available: https://www.history.com/news/prohibition-organized-crime-al-capone?li_source=LI\& li_medium=m2m-rcw-history [Accessed 26 Oct 2021].

61 Comen E. These 9 states still have dry counties, 2019. Available: https://247wallst. com/special-report/2019/12/12/states-that-still-have-dry-counties/ [Accessed 26 Oct 2021]. 